J. Clin. Chem. Clin. Biochem.

Vol. 25, 1987, pp. 123-130

(C) 1987 Walter de Gruyter \& Co.

Berlin - New York

\title{
Gene Analysis and the Clinical Chemist ${ }^{1)}$
}

\author{
By H. Lang, W. Ebeling, B. Reckmann and E. Rieke
}

Biochemical Research Institute, E. Merck Darmstadt, Darmstadt, Federal Republic of Germany

(Received January 15/February 27, 1987)

Summary: Knowledge of gene analysis methods and concepts will be important to the clinical chemist in the near future. Currently most gene analyses must be performed by indirect techniques, using polynucleotide probes hybridizing close to or on the disease gene but not on the position of the mostly unknown gene mutation (restriction fragment length polymorphism analysis). The sensitivity and specificity of such assays are affected by biological and methodologic factors, and are being continually improved. Preventive medicine is a promising area for gene analysis which will possibly fit well into the domain of clinical chemistry. The application of nucleotide hybridization analysis in tissue matching for organ transplantation, and in the detection and differential diagnosis of malignancies is in its early stages. A very promising, and rapidly emerging, technology is the direct detection and differentiation by gene probing of bacteria and viruses in medical microbiology. Guidelines for the ethical problems of gene analysis already exist within the field of medical ethics.

\section{Introduction}

Modern methods of genè analysis can be applied to many fields of medicine. This presentation attempts to assess the impact of gene analysis on clinical chemistry, as seen by a clinical chemist. The discussion focuses on three topics:

(1) methodological characteristics,

(2) some of the applications of gene analysis, and

(3) the public debate about the impact of gene analysis on the individual and society.

\section{Methodology}

Several aspects of polynucleotide hybridization technology need to be further developed' for routine use in clinical chemistry. The main goals for this development are to increase the specificity, sensitivity, and speed of analysis, to make the use of radioactive labelling unnecessary, to automate analysis, and to increase the cost/benefit ratio.

1) Revised manuscript of a lecture presented in the workshop on "Analysis of Genetic Defects by Molecular Biology Methods" at the Congress "Biochemical' Analysis 86", Munich, June 2, 1986.
Table 1 reviews the different procedures of hybridization technology. Some subheadings have been added under the "Southern blot" technique to demonstrate the improvements in cleavage and separation of DNA/RNA. The Southern blot technique is addressed in figure 1 , which depicts in a very simplified way the two basic forms of application:

direct analysis, with probes hybridizing directly on, the position of a gene defect, and

indirect analysis, with probes hybridizing in a position close to, but not directly on, the gene defect itself. The latter is called restriction fragment length polymorphism (RFLP) analysis, because the length of the DNA fragment visualized with the probe differs depending on the presence or absence of a gene mutation.

Today only a few gene defects can be analyzed with direct probes; indirect restriction fragment length polymorphism methodology has to be used for the majority of tests (8). This technique, however, only provides statistical evidence: a positive or negative test result is based on the establishment by analytical and biostatistical methods of a reliable correlation 
Tab. 1. Gene analysis: Procedures $(1-4)$.

\begin{tabular}{ll}
\hline Procedure & Example \\
\hline In situ hybridization & Chromosomal localization \\
Dot blot technique & Semiquantitative detection of extracted DNA \\
Colony hybridization & $\begin{array}{l}\text { Dot blot for bacterial cultures } \\
\text { Plaque hybridization }\end{array}$ \\
Sourthern blot & RFLP, point mutations, deletions, etc. \\
Conventional restriction enzymes & \\
"Universal" restriction enzymes (5) & (Homogeneous technique) \\
"Oligomer restriction" (6) & (Separation of high molecular weight DNA) \\
Pulsed field electrophoresis $(7)$ & Gene detection with m-RNA \\
\hline
\end{tabular}

Direct Analysis

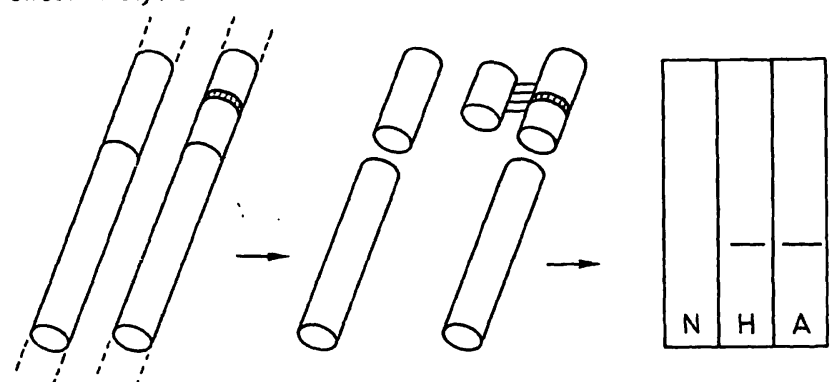

Indirect Analysis: Restriction Fragment Length Polymorphisms

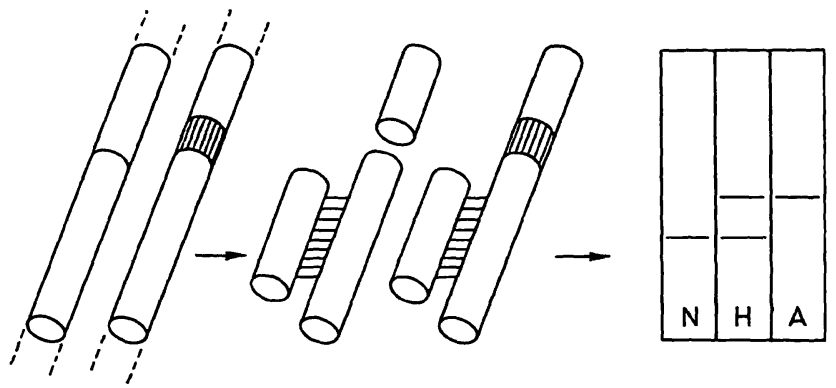

Fig. 1. Gene analysis: "Southern blot" technique. Schematic representation of a gene section with cleavage sites for restriction enzymes. Direct analysis: A probe is available binding on the gene mutation. After cleavage, on the separation gel a band will be detected in the samples from homozygous and heterozygous persons. Indirect analysis: A probe is available binding in some distance from the gene mutation. When the mutation eliminates the restriction cleavage site, the probe will mark a band of higher molecular weight in the separation gel. Normals show a band of lower molecular weight, homozygous patients show a band of higher molecular weight, heterozygous carriers show both bands.

$\mathrm{N}=$ normal person, $\mathrm{H}=$ heterozygous carrier, $\mathrm{A}=$ affected homozygous patient, = gene mutation

("linkage") between appearance of a defined restriction fragment and a gene defect $(1,9)$. This is usually achieved by moving the probes stepwise closer to the gene defect ("gene walking, gene jumping") until a "direct" probe has been found (10).
The clinical chemist is basically interested in judging the validity of diagnostic information obtained with gene analysis methods. Both biological and methodological factors influence the sensitivity and specificity of the results. Some examples of biological factors affecting the validity of test results are described below.

- Association of disease with the marker gene chosen: This affects the risk prediction for diseases. If HLA gene polymorphisms are uised to predict the risk for type I diabetes, the sensitivity is only about $30 \%$, because the disease and the marker gene are only loosely associated (11).

- Penetrance of gene defects: This affects the risk prediction for disease manifestation. Penetrance is the percentage of gene-defect carriers with manifest disease. The sensitivity of predicting cancer risk for specific organs by testing for (activated) oncogenes is about $50 \%$ because most of the tissue located oncogenes have a penetrance of this order of magnitude (13). The sensitivity of predicting the risk for Huntington's disease by testing for a direct Huntington marker would be nearly $100 \%$, because this disease has an almost absolute penetrance (14).

- Genetic constellation of the family: The linkage of diseases with genetic markers depends upon the genetic constellation of a family; it is "family specific". Assessment of the risk for genetic diseases with restriction fragment length polymorphism markers is only possible after the linkage has been established by testing as many members of the patients family as possible (15).

- Linkage of marker genes with gene defects: This affects the error probability of gene analysis. The problem has already been addressed with regard to restriction fragment length polymorphism 
methodology. The linkage depends upon the distance between the gene defect and the marker position. The greater the distance, the greater the probability of a crossing over during the meiotic phase of cell division, resulting in uncoupling of the marker from the defect position. The unit of measure for this distance is the Morgan: one centiMorgan is equivalent to about one million base pairs, and this distance is - with notable exceptions - equivalent to a crossing over probability of $1 \%$, which means an error probability of $1 \%$ (16). For instance, the Huntington marker of $\mathrm{Gu}$ sella (1983) binds at a distance of $5 \mathrm{c}$-Morgan from the gene defect. Therefore the sensitivity of a positive test with this marker is $95 \%$ (14). A good marker should be positioned at a distance of less than $0.2 \mathrm{c}$-Morgan from the gene defect, which translates to a sensitivity of $99.8 \%$ (9). The sensitivity can be improved considerably by using two probes binding on both sides of a gene defect.

Some methodologcical factors that have significant effects on the sensitivity and specificity of hybridization assays are the choices of technique and labelling system, degree of separation attained, length of the DNA used as a probe, and the nucleic acid selected for hybridization. Most of these problems are self-evident to the clinical chemist, so only two of them will be addressed further.

- The signal-generating label system used is directly responsible for the assay sensitivity. Table 2 shows a few examples of the large variety of labels published. The standard label is ${ }^{32} \mathrm{P}$, resulting in an absolute sensitivity of $0.5 \mathrm{pg}$ DNA. In recent years, great efforts have been made to develop non-radioactive detection systems. With the most elaborate enzyme-labelled biotin-avidin systems, a sensitivity of $1 \mathrm{pg}$ DNA is routinely obtained. It is only a matter of time until non-radioactive labels will be available that give equal or better sensitivity than the ${ }^{32} \mathrm{P}$ label.

Tab. 2. Gene analysiș: Labeling of probes $(3,17,18)$.

\begin{tabular}{ll}
\hline Radioactive labels & Absolute sensitivity \\
DNA - ${ }^{32} \mathrm{P}$ & $0,5 \mathrm{pg}$ \\
DNA - ${ }^{3} \mathrm{H} /{ }^{35}$ S (In situ hybridization) & \\
Non-radioactive labels & \\
DNA - Fluorochrome & $100 \mathrm{pg}$ \\
DNA - Enzyme & \\
DNA - Antibody - Enzyme & \\
DNA - Hapten - Antibody - Enzyme & \\
DNA - Biotin - Avidin - Enzyme & 1 \\
DNA - Luminol - Activator - DNA & $?$ \\
DNA - Biotin - Antibody - Gold & (In situ \\
& hybridization) \\
\hline
\end{tabular}

- Assay sensitivity and specificity can be greatly enhanced by hybridization with nucleic acid species other than chromosomal DNA. Table 3 summarizes the variants used in gene analysis. In clinical microbiology, for instance, the use of probes for RNA in bacterial ribosomes makes it possible to detect bacteria with greater sensitivity. r-RNA is present in higher concentration than chromosomal DNA: up to 5000 copies per cell.

Tab. 3. Gene analysis: Optimization of hybridization.

\begin{tabular}{|c|c|c|}
\hline \multicolumn{3}{|c|}{ Goal: Increasing sensitivity } \\
\hline Probe & Analyte & Example \\
\hline DNA & DNA & $\begin{array}{l}\text { Kinetics of association: precipi- } \\
\text { tants }\end{array}$ \\
\hline $\mathrm{n}(\mathrm{DNA})$ & DNA & Several probes \\
\hline DNA & m-RNA & Increased stability of binding \\
\hline DNA & r- RNA & Higher copy number (19) \\
\hline
\end{tabular}

Goal: Increasing specificity

$\begin{array}{cll}\text { Probe } & \text { Analyte } & \text { Example } \\ \text { DNA } & \text { m-RNA } \because: & \text { In situ: gene activation (20) } \\ \text { DNA } & \text { p-DNA } & \text { Antibiotics resistance (21) } \\ & \cdot & \text { Enterotoxin genes (22) }\end{array}$

Table 4 surveys the variety of sample materials that can be used for hybridization assays. It is interesting that modern cell sorting equipment has made it possible to isolate fetal cells from the mother's blood cells ( 1 fetal cell in 2.5 million blood cells). This technique will possibly facilitate prenatal screening procedures.

Tab. 4. Gene analysis: Sample materials.

\begin{tabular}{|c|c|}
\hline Sample materials & Application (examples) \\
\hline Blood & Infection: bacteria, viruses \\
\hline Blood cells (nucleated cells) & $\begin{array}{l}\text { Genetic diseases } \\
\text { Malignant diseases } \\
\text { Identity } \\
\text { Exposure }\end{array}$ \\
\hline Tissue cells & $\begin{array}{l}\text { Genetic diseases } \\
\text { Tissue typing (transplantation) } \\
\text { Disease predisposition } \\
\text { Oncogenes }\end{array}$ \\
\hline Tissues & $\begin{array}{l}\text { In situ hybridization: } \\
\text { Papilloma virus infection }\end{array}$ \\
\hline Fibroblast cultures & Genetic disease carriers \\
\hline Sperm cells & Identity \\
\hline Hair roots & Identity \\
\hline Feces & Infection: viruses \\
\hline $\begin{array}{l}\text { Fetal cells } \\
\text { from amniotic fluid } \\
\text { from chorionic villi } \\
\text { from maternal blood }\end{array}$ & Genetic diseases \\
\hline Chromosomes & Genetic research: gene mapping \\
\hline
\end{tabular}




\section{Application of Gene Analysis}

Application of the hybridization technique should be restricted to areas in which it has definite advantages over classical techniques such as analysis of gene products by enzymatic or immunological assays. Some instances in which hybridization assays should be applied are:

(1) if therapy depends upon test result,

(2) if test accelerates diagnosis,

(3) if no gene product is known

(4) if there is no concordance between DNA and gene product,

(5) if differential diagnosis via the gene product is too complicated or inadequate, and

(6) if the test result is more accurate than with other techniques.

This list will certainly be extended in the future.

The applications for DNA/RNA probe techniques are expanding rapidly. Table 5 gives a - necessarily incomplete - list of such applications. A few of these applications which are of special interest for the clinical chemist will be discussed in some detail.

Prenatal and carrier diagnosis of genetic diseases is no topic of this review. It in principle is connected with genetic counseling and therefore is a domain of the human geneticist.

Tab. 5. Gene analysis: Areas of application.

\begin{tabular}{ll}
\hline $\begin{array}{l}\text { Area } \\
\text { Human genetics }\end{array}$ & Application \\
Genetic diseases & \\
& Prenatal and carrier diagnosis $(15$, \\
Preventive medicine & 25, 27) \\
Occupational medicine & Prvironmental diseases $(14,28)$ \\
Pharmacogenetics & Chemothe toxicology $(14,25)$ \\
Malignant diseases & Diagnosis, differentiation (29) \\
Transplantation & Organ matching $(26)$ \\
Forensic medicine & Human linkage $(23,24)$ \\
Heterologous insemination & Donor testing $(25)$ \\
Genetic research & Cytogenetics $(30,31)$
\end{tabular}

Detection of pathogens

Infectious diseases

Parasitic diseases

Bacteria, viruses $(32,33,34)$

Diagnosis, therapy monitoring (35)

Preventive medicine is an interesting application for which clinical chemists should investigate gene analysis. The goal of this investigation is to detect persons at risk for certain diseases by pinpointing gene defects. Some of the diseases for which DNA probes are available are e.g. atherosclerosis (36), alcohol intolerance $(37,37 a)$, and emphysema (38). Gene analysis would be particularly useful for identifying individuals at risk for the environmental diseases of developed countries and for diseases for which no adequate biochemical markers are available. In this connection, an intensive search for the location of genetic defects for diseases as multiple sclerosis, $\mathrm{Alz}$ heimer's disease, manic depression, 'and diabetes is in progress.

It should be realized that environmental diseases have a multifactorial etiology. In addition to genetic predisposition, factors such as the lifestyle of the individual have a significant influence on the development of these diseases. The problems of screening programs, which are well known to the clinical chemist, also apply to preventive genetic analysis. The task is not only to identify the carrier of a genetic defect, but to identify carriers of the defect who are prone to develop disease. The measure for this probability is the "relative risk". It equals the percentage of defect carriers with disease manifestations, divided by the percentage of defect carriers without disease manifestations. Thus, a predictive value of a positive test in excess of 0.9 can only be obtained in patient samples in which the prevalence of defect carriers is greater than $10 \%$ and with markers indicating a relative risk of more than 100 (39). In addition, increasing knowledge about the heterogeneity of genetic defects (see e.g. l.c. (12)) leads to a further complication in defining individual "genetic predisposition". Therefore, the value of preventive genetic health screening will be restricted to carefully selected risk groups.

A widely discussed example is occupational screening: the attempt to assess the risk for employees ("hypersusceptibility") by detecting genetic predispositions for occupational hazards, e.g., exposure to chemicals, air pollution, or extreme stress situations. Some chemical companies, as well as some government agencies in the U.S., have been utilizing such tests. However, as has been pointed out with regard to preventive health testing, the problems of multifactorial etiology and statistical significance apply to occupational testing. In addition, the genetic markers tested are not necessarily associated with susceptibility, and no cost/benefit analyses have been performed. Accordingly, the responsible authorities have stopped performing these tests in most cases. Intensified ecogenetic research is necessary to provide a firm basis for such activities $(14,25,40)$.

A field of great promise is pharmacogenetics. The possibility to determine the "genetic phenotype" of patients regarding their response to drugs certainly will be an important step in optimizing chemotherapy. 
It is of considerable interest to the work of the clinical chemist to note how laboratory testing in the field of malignant diseases will be influenced by the hybridization technique. It is difficult to predict the extent to which gene analysis will advance the use of biochemical techniques in cancer management. However, in some cases the use of DNA probes has already been proven to have a definite advantage in the detection or differential diagnosis of cancer, as shown in table 6.

Tab. 6. Gene analysis: Diagnosis of malignant diseases.

Immunoglobulin synthesis $(29,41)$

Southern blot analysis with probe against chromosomal immunoglobulin genes

Detection of malignant B-cell clones

Diagnosis of lymphomas

Receptors (29)

Southern blot analysis with probe against T-cell receptor gene Diagnosis of acute lymphoblastic leukaemias

Oncogenes (1, 41-43)

1. Chromosomal translocations

Detection in situ, restriction fragment length polymorphism in development

2. Gene amplification

Southern blot analysis with probe against chromosome 13 fragments

Diagnosis of retinoblastomas

- The detection of malignant B-cell clones is important in the differential diagnosis of non-Hodgkin lymphomas. Today, DNA probes are available for particular regions of chromosomal immunoglobulin genes. New restriction patterns are constantly being generated as a consequence of intrachromosomal gene rearrangement; the cell-specific IgG molecule is a different one in each new Bcell clone. Normally, these clonal immunoglobulin species cannot be detected by restriction analysis, because the fraction of each new B-cell clone is too small to be detected. However, if a malignant clone increases to constitute more than $1 \%$ of the total clone population, its band in the hybridization assay becomes prominent.

- Detection of chromosome translocations is of definite value in the differential diagnosis of leukaemia induced by activated oncogenes. For example, proof of the translocation of sis and abl oncogenes between chromosomes 9 and 22 is a definitive marker in the diagnosis of chronic myelocytic leukaemia. Today testing is done by cytogenetic techniques (including DNA probes), but probes for use in the restriction fragment length polymorphism technique are being developed. The problem is that in the process of translocation the points at which chromosomes break vary over a distance of about 25 kilobases; this leads to some ambiguity in the evaluation of restriction fragment length polymorphism patterns.

A straightforward application of hybridization assays is the detection of foreign RNA and DNA to diagnose bacterial and viral infections in humans. Accordingly, much effort is being spent to develop routine techniques for use in medical microbiology. Table 7 summarizes the infectious diseases for which probes or test kits are available. The analytical problems of this methodology are threefold:

- Low sensitivity of assays (the detection limit for bacteria today is about $10^{3}$ cells; for viruses it is $10^{4}-10^{5}$ genome copies) $(29,34)$;

- Radioactive labelling must still be used; and

- Preconcentration, e.g. culturing, of samples is necessary.

Tab. 7. Gene analysis: Infectious diseases $(1,3,17,33,34,44)$.

Disease/Organism Probes Test

1. Bacterial Diseases

1.1 Enterobacteria:

$$
\text { E. coli, Salmonella }
$$

Yersinia

1.2 Non-Enterobacteria:

Campylobacter

Legionella, Bordetella, Vibrio

Streptococci, Staphylococci

kits

2. Sexually transmitted diseases

Herpes simplex virus, types I and II

Neisseria gonorrhoeae

Chlamydia

AIDS

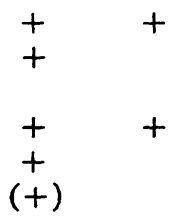

3. Viruses

3.1 Viruses in blood

Hepatitis virus $A$

Hepatitis virus B

Hepatitis virus non- $A /$ non- $B$

Cytomegalovirus, adenovirus, rubellavirus, Epstein-Barr virus

3.2 Viruses in stool

Rotavirus

3.3 Viruses in tissues

Papillomavirus

$\begin{array}{ll}+ & (+) \\ + & + \\ + & (+) \\ + & +\end{array}$

$+$

$(+)$

Parasites

Malaria

$+$

It can be anticipated that these methodological shortcomings will be resolved within a short time.

An example of the use of DNA probes in medical microbiology is their application in the diagnosis 
of bacterial infections. In addition to increasing the sensitivity and speed of analysis, emphasis has been placed on developing more specific assays. For instance, by using probes for plasmid DNA, evidence can be obtained about the antibiotic resistance patterns (21), or about specific auxotypes (32). In addition, by using probes specific for toxin genes, evidence can be generated about the ability of $E$. coli to produce endo- and exotoxins.

\section{Implications for the Clinical Chemist}

Because of the many areas to which hybridization assays can be applied, the clinical chemist is interested in learning what impact these new techniques might have on his laboratory, and when.

Table 8 summarizes the predictions of several professional market analysts. It shows that the hybridization technique will have a strong impact on medical microbiology within the next few years and will complete or replace some of the classical bacteriological and viral culture techniques and some of the immunological methods that have just appeared on the market (45). Within 5 years laboratories are foreseen to routinely use hybridization assays rather than immunological methods for tissue typing and as a replacement for the analysis of gene products in screening for genetic disease. By the late 1990's hybridization assays hopefully can be routinely used to diagnose cancer.

Table 8. Gene analysis: Market trends.

\begin{tabular}{lccccc}
\hline Estimates for worldwide market (Millions US \$) \\
Year & 1985 & 1986 & 1988 & 1990 & 2000 \\
\hline Total & 2 & 15 & 50 & 250 & 650 \\
Infectious diseases & 2 & 25 & 45 & 100 & 400 \\
Transplantation & - & - & 5 & 20 & 50 \\
Genetic diseases & - & - & 1 & 25 & 100 \\
Cancer & - & - & - & 1 & 100 \\
\hline
\end{tabular}

Sources: Frost \& Sullivan

Robert S. First

Drexel Burnham Lambert

Clinica

\section{Public Debate}

In the course of the controversy about the merits and risks of modern biology, the public has been made aware that gene analysis is a technique which could be used to infringe upon the basic rights of the individual. In many ways this debate has become irrational and emotional $(14,28,46,47)$. For exam- ple, the use of gene analysis in occupational screening could be considered preventive medicine, but it could also be used for genetic exploration of employees or to bar certain classes of employees from holding certain positions.

To identify aspects of the controyersy on which the clinical chemist must take a position, it is necessary to look at the arguments rationally. Table 9 shows some points that must be considered in evaluating the impact of gene analysis on the individual and on society. As can be seen, arguments have been presented for and against these points.

Tab. 9. Gene analysis: Areas of contradictory opinion (14, 25, $28,46,48,49,50,51)$.

\begin{tabular}{ll}
\hline Individual rights & $\begin{array}{l}\text { 1. Preventive medical examinations do } \\
\text { not violate human dignity }\end{array}$ \\
& $\begin{array}{l}\text { 2. Knowledge of predisposition before } \\
\text { manifestation of disease may violate } \\
\text { the individual's rights }\end{array}$ \\
Labour & $\begin{array}{l}\text { 1. Responsibility of employers for welfare } \\
\text { of employees }\end{array}$ \\
2. Restriction of individual rights of em- \\
ployees
\end{tabular}

One example is the area of "social aspects." It is valid to ask about the extent to which society should carry the burden for groups with "protected handicaps." An argument could be made in favor of large scale prenatal and preventive screening; an equally valid counter-argument is the duty of society to care for its disabled and diseased, which is even included in the German constitution (52). Another example is the area of "data protection." The duty of the authorities to protect citizens from harm would lead to a system of disease prevention coupled with some degree of social pressure and handling of personal data. This is counterbalanced by the right to selfdetermination, an argument based on the rights of personality that denies to authorities any right to acquire or utilize personal data. At present there is no consensus on the arguments about gene analysis. As a result, various groups have formulated policies about how gene analysis should be handled $(53,54)$. 
The clinical chemist searching for guidelines for his involvement in gene analysis should particularly consider ethical questions concerning the analysis and interpretation of the human genome $(46,49,50,51$, $55,56)$. These questions include the rights of individuals as opposed to the rights of society, and protection of the ill and disabled. Arguments concerning "genetic health" are irrelevant because the effects of genetic counseling, as the experts agree, will not change to a significant degree the gene pool of our population. According to professional authorities in the field of ethics, it will not be necessary to formulate special "gene ethics," because all problems can be solved by means of existing medical ethics (56). Rules that the clinical chemist can follow in his work include adherence to the responsibility principle of ethics. This means that he has to consider and to take the responsibility for the possible consequences of his work $(50,51,57)$. It is considered necessary to attain consensus of the scientists engaged in gene analysis by involving the medical ethics commissions $(48,52)$.

An objective and detailed consideration of ethical problems in gene analysis was provided by the 1983 report of the President's Commission for the Study of Ethical Problems in Medicine and Biomedical and Behavioral Research (58). The commission advocates that five conditions be met to ensure the use of gene analysis to benefit the individual. These conditions are confidentiality, autonomy (individual choice),

\section{References}

1. Sauls, C. D. \& Caskey, C. T. (1985) Clin. Chem. 31, 804-811.

2. Dorkins, H. R. \& Davies, K. E. (1985) Trends in Biotechnology 3, 195-199.

3. Wolf, H., Leser, U., Motz, M. \& Seibl, R. (1986) Lab. Med. 10, 229-234.

4. Wulff, K. (1986) Arzneim.-Forsch./Drug Res. 36, 157-161.

5. Szybalski, W. (1985) Gene 40, 169-173.

6. Saiki, R. K., Arnheim, N. \& Erlich, H. A. (1985) Biotechnology 3,1008 $=1012$.

7. Smith, C. L. \& Cantor, C. R. (1986) Nature 319, 701-702.

8. Cooper, D. N. \& Schmidtke, J. (1984) Hum. Genet. 66, $1-16$.

9. Emery, A. E. H. (1976) Methodology in Medical Genetics, Churchill Livingstone, Edinburgh/London/New York, pp. 63-75.

10. Little,' P. (1986) Nature $321,558-559$.

11. Deufel, T., Gerbitz, K.-D. \& Boenke, B. (1986) Mitt. Dt. Ges. Klin. Chemie 17, 105-109.

12. Antonarakis, S. E., Kazazian, H. H. \& Orkin, S. H. (1985) Hum. Genet. 69, 1-14.

13. Knudson, A. G. (1985) Cancer Res. 45, 1437-1443.

14. Kolata, G. (1986) Science 232, 317-319.

15. Kazazian, H. H. (1985) Clin. Chem. 31, 1509-1513.

16. Botstein, D., White, R. L., Skolnick, M. \& Davis, R. W. (1980) Am. J. Hum. Genet. 32, 314-331.

17. Klausner, A. \& Wilson, T. (1983) Biotechnology I, $471-478$. knowledge (instruction), well-being (usefulness via well organized programs), and equity (equal access of all groups). However, the Commission also believes that overemphasis on individual rights may cause harm to other persons, e. g., children or the disabled. In such cases, it may be necessary to perform lowrisk procedures.

Another set of recommendations, also covering the implications of gene analysis, was developed in 1985 by the International Conference on Bioethics in France (59). Meanwhile, the report of the EnqueteKommission "Chancen und Risiken der Gentechnologie" (61) has been published, which contains a detailed analysis of the situation in Germany. Special reference to the situation of the clinical chemist will be given in the document "The Role and Responsibilities of the Clinical Chemist" which is being prepared by IFCC (60).

In spite of all questions and problems connected with the application of gene analysis to human beings, in an educated society it could lead to an improved quality of life, as the President's Commission foresees (58):

"In sum, the fundamental value of genetic screening and counselling is their ability to enhance the opportunities for individuals to obtain information about their personal health and childbearing risks and to make autonomous and noncoerced choices based on that information."
18. Tchen, P., Fuchs, R. P. P., Sage, E. \& Leng, M. (1984) Proc. Nat. Acad. Sci. USA 81, 3466-3470.

19. Shaw, S., Dean, E. \& Kohne, D. E. (1985) Proc. 85th Meeting Am. Soc. Microbiol., Washington, D. C.: Am. Society for Microbiology.

20. Berger, C. N. (1986) Embo J. 5, 85-93.

21. Gootz, T. D., Tenover, F. C., Young, S. A., Gordon, K. P. \& Plorde, J. J. (1985) Antimicrob. Agents Chemother. 28, $69-73$.

22. Hill, W. E. \& Payne, W. L. (1984) J. Assoc. Off. Anal. Chem. 67, 801-807.

23. Jeffreys, A. J., Wilson, V. \& Thein, S. L. (1985) Nature $316,76-79$.

24. Gill, P., Jeffreys, A. J. \& Werrett, D. J. (1985) Nature 318 , $577-579$.

25. Rowley, P. T. (1984) Science 225, $138-144$.

26. Giphart, M. J. (1984) Applications of c-DNA Probes in HLA Tissue Typing: Advantages and Disadvantages. Robert S. First Conference, Düsseldorf, Germany, Nov. $19-20$.

27. Driesel, A. J. (1985) Einsatz von DNA-Sonden zur Erfassung genetischer Defekte beim Menschen, Ferd. Enke-Verlag, Stuttgart.

28. Hunt, M. (1986) The Total Gene Screen: New York Times Magazine, Jan. 19, p. $33 \mathrm{ff}$.

29. Sklar, J. (1985) Human Pathol. 16, 654-658.

30. Langer, G., Blin, N. \& Stoehr, M. (1984) Histochemistry $80,469-473$. 
31. Human Gene Mapping 8 (Report, 8. Internat. Workshop on Human Gene Mapping). (1985) Cytogenetics and Cell Genetics 40, Nos. 1-4.

32. Totten, P. A., Holmes, K. K., Handsfield, H. H., Knapp, J. S., Perine, P. L. \& Falkow, S. (1983) J. Infectious Diseases $148,462-471$.

33. Berry, A. J. \& Peter, J. B. (1984) Diagn. Med. 7, 62-72.

34. Highfield, P. E. \& Dougan, G. (1985) Med. Lab. Sci. 42, $352-360$.

35. Barker, R. H., Suebsaeng, L., Rooney, W., Alecrim, G. C., Dourado, H.V. \& Wirth, D. F. (1986) Science 23.1, 1434-1436.

36. Funke, H., Rust, S. \& Assmann, G. (1986) Clin. Chem. 32, 1285-1289.

37. Braun, T., Grzeschik, K. H., Bober, E., Singh, S., Agarwal, D. P. \& Goedde, H. W. (1986) Hum. Genet. 73, 365-367.

37a. Goedde, H. W. \& Agarwal, D. P. (1986) In: Ethnic Differences in Reactions to Drugs and Xenobiotics, Alan R. Liss Inc., New York, pp. 113-138.

38. Kalsheker, N., Chiswell, D., Markham, A., Imam, A., Wallis, S., Williamson, R. \& Humphries, S. E. (1985) Ann. Clin. Biochem. 22, 25-32.

39. Lander, E. \& Botstein, D. (1986) Mapping Complex Traits in Humans. Cold Spring Harbour Symp. Quant. Biol. Vol. $5 I$.

40. Canter, E. F. (1984) Am. J. Law Med. 10, 323-347.

41. Ellis, K. P. \& Davies, K. E. (1985) Biochem. J. 226, 1 -11.

42. Pimentel, E. (1985) Cancer Genet. Cytogenet. 14, 347-368.

43. Weiss, R. A. \& Marshall, C. J. (1984) Lancet II, $1138-1142$.

44. Eisenstein, B. I. \& Engleberg, N. C. (1986) J. Infectious Diseases $153,416-430$.

45. Orr, T. (1986) Genetic Engineering News 6, 1.
46. Benda, E. (1985) In: Genforschung - Fluch oder Segen? (Flöhl, R., ed.) J. Schweitzer-Verlag, München, pp. 205-231.

47. Bleicher, S. (1984) Quelle 10/1984, pp. 521-523.

48. Benda, E. (1985) Neue Jurist. Wochenschr., No. 30, pp. 1730-1734.

49. Zimmerli, W. C. (1985) In: o.c. (46), pp. 59-85.

50. Eser, A. (1985) In: o. c. (46), pp. $248=258$.

51. Jonas, H. (1985) In: o.c. (46), pp. 1 $1+15$.

52. Eser, A. (1985) In: Gentechnologie und Verantwortung, Berichte und Mitteilungen der Max-Planck-Gesellschaft, No. $3 / 1985$, pp. $53-64$.

53. In-vitro-Fertilisation, Genomanalyse und Gentherapie. Bericht der gemeinsamen Arbeitsgruppe des Bundesministeriums für Forschung und Technologie und des Bundesministeriums für Justiż, J. Schweitzer-Verlag, München, 1985.

54. Walter, J. (1986) "Ḧandlungsbedarf und Empfehlungen für Genetische Analysen an Arbeitnehmern", Arbeitspapier für die Enquete-Kommission, 21. 03. 1986.

55. Böckle, F. (1985) In: 1.c. (52), pp̃. 65-77.

56. Reiter, J. (1985) In: o.c. (46), pp. 198-204.

57. Löw, R. (1985) Leben aus dem Labor, Bertelsmann, München, pp. 97-101

58. Screening and Counseling for Genetic Conditions: President's Commission for the Study of Ethical Problems in Medicine and Biomedical and Behavioral Research, Washington, D. C., 1983, pp. 5-8.

59. Eser, A. (1985) In: 1.c. (52), pp. 81-88.

60. Ethics in Clinical Chemistry, IFCC News 1985, No. 1, p. 6.

61. Catenhusen, W.-M. \& Neumeister, H. (Hrsg.) (1987) Enquete-Kommission des Deutschen Bundestages. Dokumentation des Berichtes: Chancen und Risiken der Gentechnologie. J. Schweitzer-Verlag, München.

\author{
Dr. Hermann Lang \\ Biochemical Research Institute \\ E. Merck \\ Postfach 4119 \\ D-6100 Darmstadt 1
}

